\title{
Faktor - Faktor Yang Mempengaruhi \\ Permintaan Jamur Tiram (Pleurotus \\ Ostreatus) \\ (Studi Kasus: Kabupaten Deli Serdang)
}

\author{
Syarifah Aini ${ }^{1}$, Siti Mardiana M.Si², Rahma Sari Siregar ${ }^{3}$ \\ Prodi Agribisnis FakultasPertanian, Universitas Medan Area \\ Email: mardiana@uma.ac.id
}

\begin{abstract}
ABSTRAK
Penelitian ini bertujuan untuk mengetahui bagaimana permintaan terhadap jamur tiram di Kabupaten Deli Serdang dan faktor-faktor apa saja yang mempengaruhi permintaan jamur tiram di Kabupaten Deli Serdang. Penelitian ini dilaksanakan dari bulan Agustus sampai September 2017. Metode pengambilan sampel untuk sampel konsumen jamur tiram menggunakan metode snowball sampling ,yaitu berdasarkan informasi satu konsumen tetap dari petani jamur tiram ke konsumen berikutnya sebanyak 30 orang. Metode analisis yang digunakan adalah uji regresi linier berganda. Hasil penelitian menunjukkan bahwa rata-rata permintaan konsumen jamur tiram di Kabupaten Deli Serdang adalah 4 sampai dengan 9 $\mathrm{kg} /$ bulan.Faktor - Faktor yang mempengaruhi secara serempak memiliki nilai signifikan terhadap permintaan jamur tiram di Kabupaten Deli Serdang yaitu harga jamur tiram, harga sayuran lain, jumlah anggota keluarga, pendapatan dan selera. Secara parsial bahwa harga sayuran lain dan pendapatan berpengaruh nyata terhadap permintaan jamur tiram dengan nilai t-hitung untuk variabel harga sayuran lain lebih besar dari t-tabel 3,302 > 1,711 yaitu nilai signifikansi lebih kecil dari alpha $0,003<0,05$, sedangkan untuk variabel pendapatan nilai t hitung 2,507 >1,711 dengannilai signifikansi 0,019<0,05.
\end{abstract}

\section{Kata Kunci : Permintaan, JamurTiram, Sayuran Lain.}

\begin{abstract}
The purpose of this study is to find out how the demand for oyster mushrooms in Deli Serdang District and what factors affect the demand of oyster mushrooms in Deli Serdang district. The sampling method was conducted by using the census method, is sampling where the existing population was taken all to be sampled. Samples in the research location there were 8 farmers, therefore all farmers in the study sites were sampled. Samples were taken $100 \%$ of the oyster mushroom population in the study sites. As for the sample of oyster mushroom consumer using snowball sampling method, that is based on information of one respondent obtained from the main respondent's recommendation as many as 30 people. The data obtained is processed then analyzed by multiple linear regression methodwith the help of SPSS 21.0. The results showed that the average consumer demand of oyster mushrooms in Deli Serdang Regency is 4 to $9 \mathrm{~kg} /$ month. Factors - Factors that affect the demand of oyster mushrooms Partially that the price of other vegetables and income significantly affect the demand for oyster mushrooms with the value of t-count 3.302 for other vegetable price variables greater than t-table 1.711 is a value of significance 0.003 smaller than alpha 0,05 , while for income variable $t$ value 2.507 bigger than t-table 1,711 and significance value 0,019 smaller 0,05 .
\end{abstract}

Keywords: Demand, Oyster Mushroom, Other Vegetables. 


\section{PENDAHULUAN}

Sektor pertanian di Indonesia merupakan sektor penting dalam pertumbuhan ekonomi nasional. Perkembangan sektor pertanian tidak hanya komoditas tanaman pangan, tetapi juga tanaman perkebunan dan hortikultura. Kegiatan pertanian khususnya bidang hortikultura terbagi menjadi empat golongan yaitu tanaman buah-buahan, tanaman sayuran, tanaman obat dan tanaman bunga yang semakin banyak diminati petani karena mampu memberikan keuntungan yang lebih tinggi dibandingkan dengan tanaman palawija pada areal yang sama (Samadi, 1995:11).

Jamur (Pleurotus) adalah salah satu komoditas hortikultura yang dapat digunakan untuk pangan neutraceuntical (makanan dan minuman untuk pencegahan dan pengobatan penyakit). Budidaya jamur memilki prospek yang cukup cerah di Indonesia karena kondisi alam yang sangat mendukung. Jamur memiliki manfaat yang beragam dalam kehidupan sehari-hari antara lain sebagai bahan pangan maupun sebagai bahan pembuatan obat yang dapat mengobati berbagai macam penyakit kronis. Sebagai bahan pangan, jamur tiram dapat dikonsumsi sebagai campuran sayur sop, jamur krispi maupun keripik jamur. Banyak restoran berkelas yang mengandalkan hidangan utamanya adalah berbahan dasar dari jamur, dan bisa dikonsumsi juga sebagai bahan pengobatan.

Tabel 1.Nilai Gizi Beberapa Jenis Jamur Dibandingkan dengan Bahan Makanan Lain dalam Satuan Berat Segar

\begin{tabular}{|c|c|c|c|c|}
\hline No & Jenis Makanan & Protein $(\%)$ & Lemak (\%) & Karbohidrat (\%) \\
\hline 1 & Jamur Tiram & 40.0 & - & - \\
\hline 2 & Jamur Champignon & 4.8 & 0.2 & 3.5 \\
\hline 3 & Jamur Shitake & $13.4-17.5$ & $4.9-8.9$ & $9.5-70.7 *$ \\
\hline 4 & Jamur Merang & 1.8 & 0.3 & $4-48^{*}$ \\
\hline 5 & Kentang & 2.0 & 0.1 & 20.9 \\
\hline 6 & Buncis & 2.4 & 0.2 & 7.7 \\
\hline 7 & Kubis & 1.5 & 0.1 & 4.2 \\
\hline 8 & Seledri & 1.3 & 0.2 & 3.7 \\
\hline 9 & Bayam & 2.2 & 0.3 & 1.7 \\
\hline 10 & Daging Sapi & 21.0 & 5.5 & 0.5 \\
\hline
\end{tabular}

Sumber: Pasaribu, et. al (2002)

Keterangan : *) Berdasarkan Berat Kering

(-) Tidak ada data

Kandungan gizi jamur tiram (Pleurotus Ostreatus) sangat tinggi sehingga hal tersebut menarik minat konsumen serta permintaan jamur di Kabupaten Deli Serdang. Permintaan yang tinggi tersebut menyebabkan harga jamur tiram semakin meningkat. Hal tersebut menjadi motivasi bagi petani untuk membudidayakan dan meningkatkan produksi bagi $\begin{array}{lllll}\text { produsen } & \text { jamur } & \text { agar } & \text { lebih }\end{array}$ 
Kabupaten Deli Serdang memiliki potensi hotikultura yang cukup besar. Kabupaten Deli Serdang memiliki banyak potensi sumberdaya hortikultura seperti sawah dan ladang. Sumberdaya hortikultura tersebut dimanfaatkan juga sebagai lahan untuk budidaya jamur tiram serta pengelolaannya yang dilakukan secara perorangan. Menurut data penyuluh pertanian di Kabupaten Deli Serdang tahun 2012 mengenai populasi petani yang membudidayakan jamur tiram yaitu 21 populasi petani yang membudidayakan jamur tiram yaitu meliputi Desa Limau Manis, Bandar Labuhan Pensiunan, Karanganyar, Beringin, Skip, Mencirim, Pagar Merbau I, Nogo Rejo, Namo Pinang, Bekukur, dan Patumbak I.Daerah yang memiliki populasi paling banyak yaitu di Desa Limau Manis dengan 3 populasi dan populasi yang sedikit di Desa Karanganyar, Pagar Merbau I, Nogo Rejo, dan Namo Pinang yaitu 1 populasi.

Berdasarkan pra survey yang dilakukan pada Desember 2016, populasi petani jamur tiram mengalami penurunan menjadi 8 petani yang terdapat pada desa Bangun Rejo Kecamatan Tanjung Morawa, desa Beringin Kecamatan Beringin , desa Galang Kecamatan Galang, dan desa Benteng Hilir Kecamatan Percut Sei Tuan,disebabkan kurangnya biaya produksi serta permintaan konsumen yang rendah. Hal ini sesuai dengan pernyataan dari petani jamur tiram.Namun, potensi terhadap usaha budidaya jamur tiram di Kabupaten Deli Serdang sangat kecil. Berbagai kendala yang dihadapi antara lain: adanya perbedaan kemampuan pengelolaan untuk menjalankan teknis produksi, terkendalanya dengan modal dalam biaya produksi,belum ada insentif harga yang memadai untuk produsen jamur tiram, belum ada kepastian pasar, sehingga petani enggan memproduksi komoditas tersebut (Badan Penelitian dan Pengembangan Pertanian, 2005:1).

Permasalahan utama yang dihadapi petani jamur tiram di Deli Serdang adalah belum ada kepastian pasar, menyebabkan petani tidak bisa langsung menjual produksinya. Permintaan masyarakat akan jamur tiram masih juga rendah, dikarenakan masyarakat yang kurang mengenal manfaat jamur tiram.Oleh karena itu untuk memenuhi permasalahan antara produksi dan permintaan jamur tiram maka perlu dilakukan penelitian tentang faktor-faktor yang mempengaruhi permintaan jamur tiram di Kabupaten Deli Serdang.

\section{METODE PENELITIAN}

Penelitian ini dilaksanakan di Kabupaten Deli Serdang lokasi ditentukan secara purposive (sengaja). Berdasarkan data dari Penyuluh Pertanian Deli Serdang tahun (2012) bahwa Kabupaten Deli Serdang merupakan salah satu pusat budidaya jamur tiram yang memiliki jumlah petani yang membudidayakan jamur tiram sebanyak 21 petani. Waktu penelitian dilaksanakan pada bulan Agustus sampai dengan September 2017. 
Metode pengambilan sampel petani jamur tiram dilakukan dengan menggunakan metode sensus, yaitu populasi petani di lokasi penelitian sebanyak 8 petani dan seluruh petani di lokasi penelitian dijadikan sampel. Untuk mendukung data penelitian, maka diambil data konsumen yang membeli jamur tiram dari petani sampel di Kabupaten Deli Serdang. Pengambilan sampel konsumen menggunakan metode snowball sampling, yaitu berdasarkan informasi satu konsumen tetap dari petani jamur tiram ke konsumen berikutnya sebanyak 30 orang hal ini berdasarkan teori Walpole (1992). Data yang dikumpulkan pada penelitian ini berupa data primer dan sekunder, dimana data primer menggunakan kuisioner sebagai alat bantu pengumpul data yang pokok (primer) serta melalui pengamatan langsung dan wawancara yang mendalam mengenai fakta-fakta yang telah terjadi. Data sekunder diperoleh dari laporan ilmiah, Badan Pusat Statistik (BPS) dan literatur atau referensi yang relevan dengan penelitian ini.

Metode analisis data yang digunakan untuk tujuan penelitian yang pertama yaitu permintaan jamur tiram akan di analisis secara deskriptif (kualitatif). Pengolahan data yang akan dilakukan dengan mentabulasi data secara sederhana dalam bentuk yang lebih mudah dibaca dan di interprestasikan.Tujuan penelitian yang kedua yaitu mengetahui faktor-faktor apa saja yang mempengaruhi permintaan jamur tiram yang akan dianalisis dengan model regresi linier berganda.

\section{HASIL DAN PEMBAHASAN}

Hasil penelitian menunjukkan permintaan jamur tiram di Kabupaten Deli Serdang adalah 4 sampai dengan $9 \mathrm{~kg} /$ bulan dengan persentase rata-rata $73 \%$. Konsumen yang membeli jamur tiram digunakan untuk dikonsumsi sendiri dan untuk dijual kembali. Secara lengkap permintaan jamur tiram di Kabupaten Deli Serdang dapat dilihat pada Tabel 2.

Tabel 2. Permintaan Jamur Tiram di Kabupaten Deli Serdang

\begin{tabular}{ccc}
\hline Permintaan Konsumen (Kg/Bulan & Responden & Persentase \\
\hline $4-9 \mathrm{Kg}$ & 22 & $73 \%$ \\
$10-14 \mathrm{Kg}$ & 5 & $17 \%$ \\
$15-19 \mathrm{Kg}$ & 3 & $10 \%$ \\
\hline Total & 30 & $100 \%$
\end{tabular}

Sumber: Data Primer diolah, 2017.

Permintaan jamur tiram di Kabupaten Deli Serdang terdiri dari beberapa variabel antara lain harga jamur tiram, harga sayuran lain, pendapatan, jumlah anggota keluarga, dan selera. 


\section{Faktor - Faktor Yang Mempengaruhi Permintaan Jamur Tiram}

Berdasarkan hasil perhitungan dengan menggunakan alat bantu SPSS 21, hasil yang diperoleh untuk perhitungan regresi linear berganda, faktor-faktor yang mempengaruhi permintaan jamur tiram di Kabupaten Deli Serdang yaitu harga jamur tiram, harga sayuran lain, jumlah anggota keluarga, pendapatan dan selera terhadap permintaan jamur tiram dapat dilhat pada Tabel 3.

Tabel 3. Model Summary Interprestasi Hasil Permintaan Jamur Tiram

\begin{tabular}{llrrr}
\hline Model & $\mathrm{R}$ & R Square & Adjusted R Square & Std. Error of the Estimate \\
1 &, $771^{\mathrm{a}}$ &, 594 &, 509 & 2,594
\end{tabular}

Sumber : Data Primer diolah, 2017.

Berdasarkan Tabel 2. Menunjukkan bahwa nilai $\mathrm{R}^{2}$ (koefisien determinasi) sebesar 0,594 yang artinya 59,4\% variasi variabel harga jamur tiram, harga sayuran lain, pendapatan,jumlah anggota dan selera mampu menjelaskan variabel permintaan jamur tiram. Sisanya 40,6\% dijelaskan oleh variabel model lain di luar penelitian ini.

Hasil analisis juga menunjukkan bahwa tingkat signifikansi 0,000 lebih kecil dari 0,005 atau F-hitung sebesar 7,013 lebih besar dari F-tabel 2,62. Hal ini berarti variabel harga jamur tiram, harga sayuran lain, pendapatan, jumlah anggota keluarga, dan selera berpengaruh secara serempak akan menunjukkan pengaruh nyata terhadap permintaan jamur tiram di Kabupaten Deli Serdang. Hal ini ditunjukkan dari F-sig 0,000 yang lebih kecil dari alpha $(0,005)$ atau $5 \%$ dapat dilihat pada Tabel 4.

Tabel 4. Anova Interprestasi Hasil Permintaan Jamur Tiram

\begin{tabular}{|c|c|c|c|c|c|c|}
\hline Model & & $\begin{array}{l}\text { Sum of } \\
\text { Squares }\end{array}$ & Df & $\begin{array}{r}\text { Mean } \\
\text { Square }\end{array}$ & $\mathrm{F}$ & Sig. \\
\hline \multirow{3}{*}{1} & Regression & 235,967 & 5 & 47,193 & 7,013 &, $000^{\mathrm{b}}$ \\
\hline & Residual & 161,499 & 24 & 6,729 & & \\
\hline & Total & 397,467 & 29 & & & \\
\hline
\end{tabular}

Sumber : Data Primer diolah, 2017. 
Interprestasi Hasil Perhitungan Dari Permintaaan Jamur Tiram

Tabel 5. Hasil Analisis Jumlah Permintaaan Jamur Tiram

\begin{tabular}{|c|c|c|c|}
\hline Variabel & $\begin{array}{l}\text { Koefisien } \\
\text { Regresi }\end{array}$ & t-hitung & Signifikan \\
\hline Constanta & $-\quad 18,702$ & $-1,034$ &, 312 \\
\hline $\begin{array}{l}\text { X1 = Harga Jamur } \\
\text { Tiram }\end{array}$ &, 450 & 605 &, 551 \\
\hline $\begin{array}{l}\text { X2= Harga } \\
\text { Sayuran Lain }\end{array}$ & 1,653 & 3,302 & ,003 \\
\hline $\begin{array}{l}\text { X3 = Jumlah } \\
\text { Anggota Keluarga }\end{array}$ & , 129 & ,351 & ,729 \\
\hline X4 = Pendapatan & ,001 & 2,507 & ,019 \\
\hline $\begin{array}{l}X 5=\text { Selera } \\
\mathrm{R}^{2}=0,594 \\
\text { F-tabel }=2,62 \\
\text { t-tabel }=1,711\end{array}$ &,- 067 &,- 479 & 636 \\
\hline
\end{tabular}

Hasil uji ini membandingkan t-hitung dengan t tabel. Dengan asumsi diterima H0 jika t-hitung < t-tabel atau H0 ditolak jika t-hitung > t-tabel. Jika tingkat signifikansi $<0,005$ maka Ho ditolak dan tingkat signifikansi > 0,005 maka Ho diterima.

Berdasarkan hasil pada Tabel 4. Dapat dibuat persamaan regresi linier berganda untuk melihat faktor-faktor yang mempengaruhi permintaaan jamur tiram di Kabupaten Deli Serdang.

$\mathrm{Y}=-18,702+0,450 \mathrm{X} 1+1,653 \mathrm{X} 2+0,129 \mathrm{X} 3+0,001 \mathrm{X} 4-0,067 \mathrm{X} 5+$ Eror

Keterangan :

$$
\begin{aligned}
& \mathrm{Y}=\text { Jumlah Permintaan Jamur Tiram (Kg/Bulan) } \\
& \mathrm{X} 1 \text { = Harga Jamur Tiram }(\mathrm{Rp} / \mathrm{Kg}) \\
& \mathrm{X} 2 \text { = Harga Sayuran Lain }(\mathrm{Rp} / \mathrm{Kg}) \\
& \mathrm{X} 3 \text { = Jumlah Anggota Keluarga (Orang) } \\
& \mathrm{X} 4 \text { = Pendapatan Konsumen (Rp/Bulan) } \\
& \mathrm{X} 5 \text { = Selera }
\end{aligned}
$$

Hasil persamaan regresi tersebut menunjukkan bahwa variabel harga jamur tiram, variabel harga sayuran lain, variabel jumlah anggota keluarga, variabel pendapatan, dan variabel selera secara serempak berpengaruh terhadap permintaan jamur tiram di Kabupaten Deli Serdang. 


\section{Uji t (Uji Parsial) dan Koefisien regresi}

Berdasarkan hasil analisis regresi linier berganda untuk variabel harga jamur tiram terhadap permintaan jamur tiram dengan koefisien sebesar 0,450, hal ini menunjukkan bahwa setiap kenaikan harga sebesar Rp 1.000,- maka permintaan jamur tiram akan bertambah sebesar $0,450 \mathrm{Kg}$.

Hasil uji t diperoleh t-hitung untuk variabel harga jamur tiram sebesar 0,605 yang lebih kecil dari t-tabel yaitu $1,711(0,605<1,711)$. Jika t-hitung $<\mathrm{t}$ - tabel dan nilai signifikansi lebih besar dari alpha $(0,05)$ atau nilai $0,551>0,05$ maka Hoditerima H1 ditolak. Hal ini berarti harga jamur tiram tidak berpengaruh nyata terhadap permintaan jamur tiram di Kabupaten Deli Serdang. Hal ini disebabkan karena jamur tiram merupakan jenis barang Giffen, yaitu salah satu barang yang bertentangan dengan hukum permintaan. Dimana apabila harga barang tersebut naik maka akan meningkatkan permintaan dan sebaliknya apabila harga barang turun maka permintaan akan mengalami penurunan. Sedangkan pada hukum permintaan bahwa "apabila harga mengalami penurunan, maka jumlah permintaan akan naik, dan sebaliknya apabila harga mengalami kenaikan maka permintaan akan menurun”.

Berdasarkan hasil analisis regresi linier berganda untuk variabel harga sayuran lain memiliki koefisien sebesar 1,653 yang menunjukkan bahwa setiap kenaikan harga sayuran lain maka permintaan terhadap jamur tiram akan bertambah sebesar 1,653 Kg.

Hasil uji diperoleh t-hitung untuk variabel harga sayuran lain sebesar 3,302 yang lebih besar dari t tabel yaitu 1,711 jika t hitung > t tabel maka Ho ditolak H1 diterima. Nilai signifkansi lebih kecil dari alpha $(0,05)$ atau nilai $0,003<0,05$. Hal ini berarti harga sayuran lain berpengaruh nyata terhadap permintaan jamur tiram di Kabupaten Deli Serdang. Hal ini disebabkan karena harga sayuran lain seperti kentang relatif lebih murah dibandingkan harga jamur tiram, dimana harga kentang $\mathrm{Rp}$ 8.000/Kg dan dapat diketahui bahwa kentang memiliki kegunaan yang sama dengan jamur tiram yang sama-sama menjadi pelengkap makanan dan memiliki manfaat bagi tubuh manusia.Menurut Alfred Marshall bahwa meningkatnya harga jamur tiram akan menyebabkan rendahnya permintaan jamur tiramdan karena kentang memiliki harga yang lebih murah dibanding dengan jamur tiram, maka konsumsi kentang akan meningkat.

Berdasarkan hasil analisis regresi linier berganda untuk variabel jumlah anggota keluarga (X3) memiliki koefisien sebesar 0,129, hal ini menunjukkan bahwa setiap penambahan anggota keluarga maka akan bertambah permintaan terhadap jamur tiram sebesar 0,129 . 
Hasil uji t didapatkan t-hitung untuk variabel jumlah anggota keluarga sebesar 0,351 lebih kecil dari t-tabel 1,711 yang artinya jika t-hitung < t-tabel maka Ho diterima H1ditolak. Nilai signifikansi lebih besar dari alpha $(0,05)$ atau nilai $0,729>0,05$. Hal ini berarti jumlah anggota keluarga tidak berpengaruh nyata terhadap permintaan jamur tiram.

Berdasarkan hasil analisis regresi linier berganda jumlah pendapatan (X4) memiliki koefisien sebesar 0,001 hal ini berarti bahwa setiap kenaikan pendapatan sebesar Rp 1.000,maka akan menaikkan permintaan terhadap jamur tiram sebesar $0,001 \mathrm{Kg}$.

Hasil uji t didapatkan t-hitung untuk variabel pendapatan sebesar 2,507 lebih besar dari t-tabel 1,711 yang artinya jika t-hitung lebih besar dari t-tabel artinya maka $\mathrm{H} 0$ ditolakH1diterima. Nilai signifikansi lebih besar dari alpha $(0,05)$ atau nilai $0,019<0,05$. Hal ini dapat diketahui bahwa jamur tiram adalah jenis barang Giffen yang artinya barang yang jika pendapatan kita naik, permintaan akan barang tersebut akan turun. Hal ini dikatakan bahwa ada pengaruh nyata pendapatan dengan permintaan jamur tiram di Kabupaten Deli Serdang.

Berdasarkan hasil analisis regresi linier berganda untuk variabel selera (X5) memiliki pengaruh negatif terhadap permintaan jamur tiram dengan koefisien sebesar $-0,067$, hal ini berarti bahwa apabila tingkat selera meningkat maka akan menurunkan permintaan terhadap jamur tiram sebesar $-0,067$.

Hasil uji t diperoleh t-hitung yaitu dengan nilai 0,479 yang lebih kecil dari t-tabel $1,711(0,479<1,711)$. Nilai signifikansi lebih besar dari alpha $(0,05)$ atau nilai $0,636>0,05$. Hal ini dikatakan bahwa Ho diterimaH1ditolak, sehingga dapat dikatakan bahwa tidak ada pengaruh nyata selera dengan permintaan jamur tiram. Hal ini sesuai dengan pernyataan dari konsumen jamur tiram bahwa mereka memilih untuk mengkonsumsi jamur tiram tidak karena selera, tetapi dikarenakan manfaat yang diperoleh untuk menjaga kesehatan tubuh dan aman untuk dikonsumsi. Jamur tiram juga cenderung digunakan menjadi makanan pelengkap seperti sop, tumisan, dan lainnya.

\section{SIMPULAN}

Berdasarkan uraian-uraian yang telah disusun pada bab-bab sebelumnya dan sesuai dengan data-data yang diperoleh dalam penelitian, maka dapat diambil simpulan bahwa Permintaan konsumen jamur tiram di Kabupaten Deli Serdang adalah 4 sampai dengan 9 $\mathrm{kg} / \mathrm{bulan}$ dengan persentase $73 \%$ dari keseluruhan klasifikasi permintaan jamur tiram. Faktor

- Faktor yang mempengaruhi secara serempak memiliki nilai signifikan terhadap permintaan jamur tiram di Kabupaten Deli Serdang yaitu harga jamur tiram, harga sayuran lain, jumlah anggota keluarga, pendapatan dan selera. Secara parsial bahwa harga sayuran lain dan pendapatan berpengaruh nyata terhadap permintaan jamur tiram dengan nilai t-hitung untuk 
variabel harga sayuran lain lebih besar dari t-tabel 3,302> 1,711 yaitu nilai signifikansi lebih kecil dari alpha $0,003<0,05$, sedangkan untuk variabel pendapatan nilai t hitung 2,507 > 1,711 dengan nilai signifikansi $0,019<0,05$. 


\section{DAFTAR PUSTAKA}

Cahyo, Antonius Dwi, 2014. Teori Permintaan Dan Penawaran.

Chalidin, M, 2016. Analisis Permintaan dan Elastisitas Daging Sapi Pada Tingkat Rumah Tangga di Kelurahan Sei Sikambing B, Kecamatan Medan Sunggal Medan.Universitas Medan Area, Sumatera Utara.

Lukman, 2007.Pengantar Teori Mikro Ekonomi.UIN Jakarta Press, Jakarta.

Nia, 2013. Analisis Permintaan Bawang Merah (Allium Ascalonicum L) Di Kota Medan Provinsi Sumatera Utara.

Sari, Nina Purnama, 2008. Analisis Faktor-Faktor Yang Mempengaruhi Usahatani Jamur Tiram Putih.

Sitepu, Julianto Effendy, 2010. Analisis Pendapatan Usahatani dan Saluran Pemasaran Jamur Tiram Putih di Kecamatan Taman Sari Kabupaten Bogor

Sofiana, Nur Hsb, 2016.Faktor-Faktor yang Mempengaruhi Permintaan Buah Papaya di Kota Medan. Universitas Medan Area, Sumatera Utara.

Suriawiria, unus. 2006. Budidaya Jamur Tiram. Kanisius. Cetakan Kelima Yogyakarta.

Walpole, R.E. 1992. Pengantar Statistik Edisi ke-3. PT.Gramedia Pustaka Utama.Jakarta. 